\title{
Development of 3D Multimedia as a Practical Suggestion Based on Virtual Reality
}

\author{
Martinus Mujur Rose ${ }^{1}$ Sholihin Sholihin ${ }^{1, *}$ Sarjana Sarjana ${ }^{1}$ Abdul Rakhman ${ }^{1}$ Ali \\ Nurdin $^{1}$ Nurul Akmal binti Kamaruddin ${ }^{2}$ \\ ${ }^{1}$ Department of Polytechnic Sriwijaya \\ ${ }^{2}$ Department of Polytechnic Mukkah \\ *Corresponding author. Email: sholihin@polsri.ac.id
}

\begin{abstract}
Multimedia technology is a technique in the computer field that combines more than one media in a form of communication that includes text, sound, graphics, animation, and video into a computer system. Computers in the field of multimedia and graphic design as data processors will make an information and communication system more attractive. The use of this multimedia field can be in the form of images and then make the information more alive and seem to have elements of motion, one of which is in the world of animation design for learning media. In the Covid-19 condition, students have difficulty in conducting online practicum learning. Various platforms are used to carry out the online learning process so that it needs to be supported by good facilities and the use of information technology. One of the newest innovations to get information today is Virtual Reality.

How Virtual Reality works will make it seem as if students are doing a Digital Engineering practicum at the Electrical Engineering Laboratory of the Sriwijaya State Polytechnic. In addition to displaying a visualization of the Digital Engineering practicum, this tool will be equipped with an audio explanation of the practicum. Then after the 3D object has been created, the user will need additional devices, namely VR glasses to help users enter and interact directly in the $3 \mathrm{D}$ world.
\end{abstract}

Keywords: Auto cad, Blender Application, Electronic compponent, 3D Verge, Digital system

\section{INTRODUCTION}

With the advancement of technology, practicum activities can be complemented by virtual practicumbased learning. Virtual practicum can be used as an alternative to focus students' attention in teaching and learning activities and to train students to do real practicum. Practical activities can be trained using the virtual world. [2]. In the Covid-19 condition, students have difficulty in conducting online practicum learning. Various platforms are used to carry out the online learning process so that it needs to be supported by good facilities and the use of information technology. One of the newest innovations to get information today is Virtual Reality. Virtual Reality is a technology that allows a person to perform a simulation of an object using a computer that is able to evoke a three-dimensional atmosphere so that it makes the user feel physically involved. become a trend to help improve performance and product quality. [4]. Based on this background, the researcher wants to develop 3-dimensional multimedia as a Digital Engineering Practicum Facility at the Telecommunications Engineering Laboratory, Sriwijaya
State Polytechnic. This 3-dimensional (3D) multimedia development uses Blender software, Verge 3D for Blender, and Virtual Reality Box as an additional tool to view 3-dimensional objects in real and as if real.

Based on the background that has been described previously, the problem that will be discussed in this Final Report is about how to use software using the 3 Dimensional modeling method as a Virtual Reality-based Digital Engineering Practicum Facility.

\section{SUPPORTING THEORY}

\subsection{Practicum object modeling design}

Making practicum objects using basic objects such as cubes, cylinders, and planes. Extrude, scale, drag or move, rotate and loop cut slide techniques are also used in modeling this practicum object. Extrude serves to form or draw certain parts in an object. Scale functions to adjust the scale (reduce and enlarge) an object or part of an object. Drag function to move the object to the desired area. Rotate function to rotate or rotate the object. Loop 
Cut Slide serves to divide the object into several parts, can be done by pressing the CTRL + R keys.

Table 1. Digital practicum object

\begin{tabular}{|c|c|c|}
\hline No & Objec name & Amount \\
\hline 1. & Protoboard & 1 \\
\hline 2. & IC & 2 \\
\hline 3. & LED & 4 \\
\hline 4. & Seven Segment & 1 \\
\hline 5. & Power Supply & Suffeciently \\
\hline 6. & Jumper Protoboard & 1 \\
\hline 7. & Power Supply & 1 \\
\hline 8. & Clock cable & \\
\hline
\end{tabular}

\subsection{Modelling Protoboard}

A protoboard is a plastic board that contains the terminals and wire paths that form the horizontal and vertical lines used to make electronic circuits. Consists of holes for the connection of the legs of the electronic components. The holes on the protoboard are arranged in such a way as to form a pattern according to the pattern of the connection network in it.

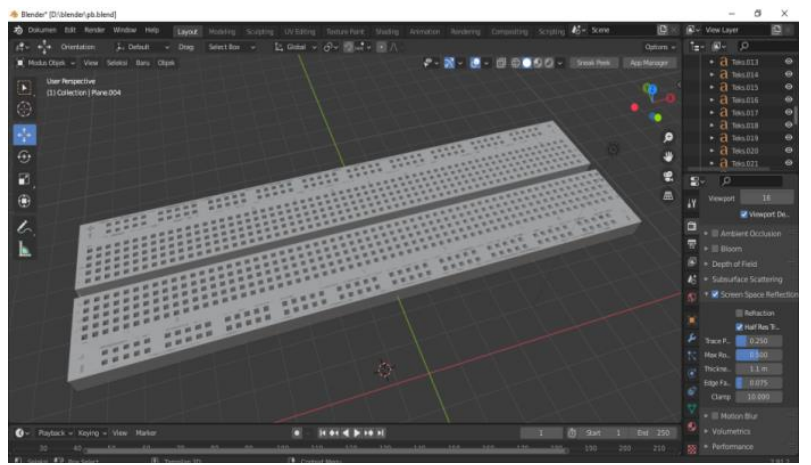

Figure 1. Modeling Protoboard

\subsection{Modelling IC}

IC is a component that is used as the brain of electronic equipment. The ICs used in the Digital Engineering Practicum are IC 7400, IC 7473 and IC 7447.

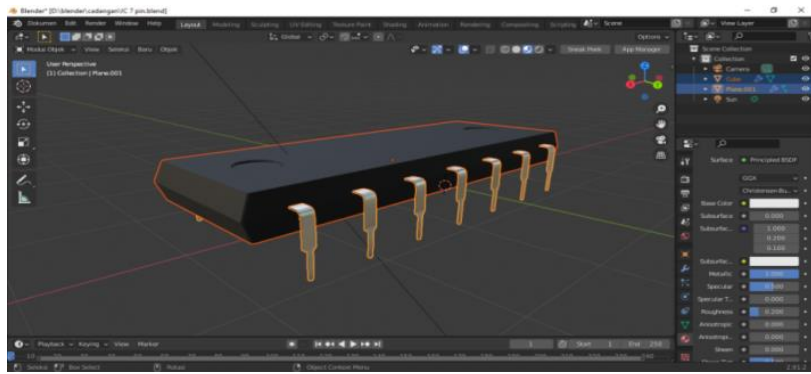

Figure 2. Modeling IC

\subsection{Modelling LED and Seven Segment}

The 7 segment display is a component that functions as a display of numeric and letter characters. 7 segment display is often also referred to as a 7 segment viewer.
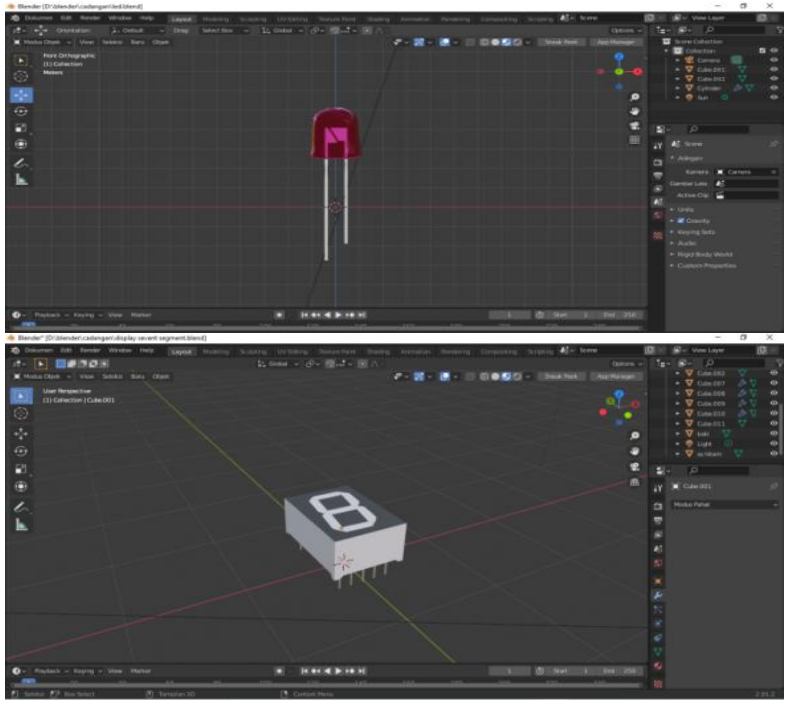

Figure 3. Modelling LED and 7 segment

\subsection{Modelling Pawer Supply}

Power Supply is a component that has a function as a voltage and electric current to other components.

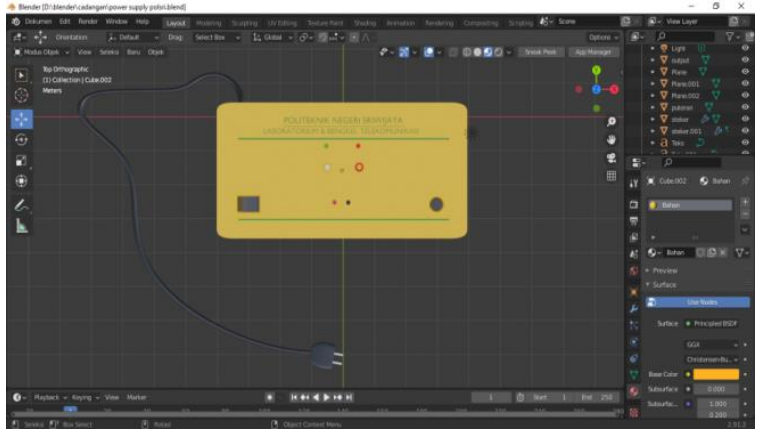

Figure 4 Modelling power supply

\section{DESIGN SYSTEM}

In designing the animation of the Digital Engineering Practicum, the researcher uses Blender software to create room objects and practicum components. The steps for designing or creating animations are doing modeling designs in Blender software, LED, IC, etc. For each object that has been designed, then texturing and material is done. Then, combine all modeling designs such as tables, etc. to form a room with the "append" feature in Blender. The interactive animation coding process was continued through Verge3D software to compose programming. Then export to virtual reality so that 
modeling and coding can be seen as if it looks real using virtual reality.

As for how to use the 3-dimensional animation software with the modeling method, namely opening the animation link from each series of experiments. This animation can be accessed via a laptop/pc and VR Box glasses. After the animation link is opened, an animation display appears as shown in Figure 5. Then, click on the command from the animation to finish doing the practicum experiment.

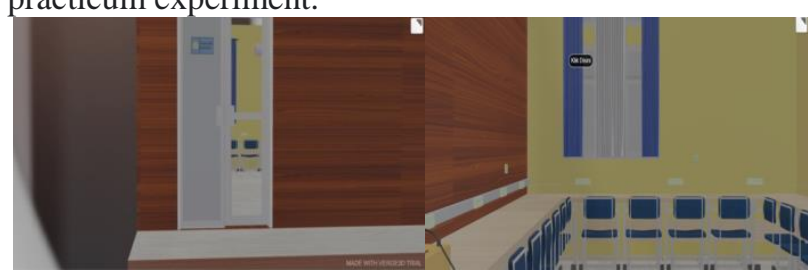

Figure 5 Digital practicum design

\section{CURRENT RESULT}

In the Digital Engineering Practicum for the RS Flip Flop circuit, it consists of several components, namely Protoboard, IC, LED, and Jumper Cables, can seen be figure. 6.

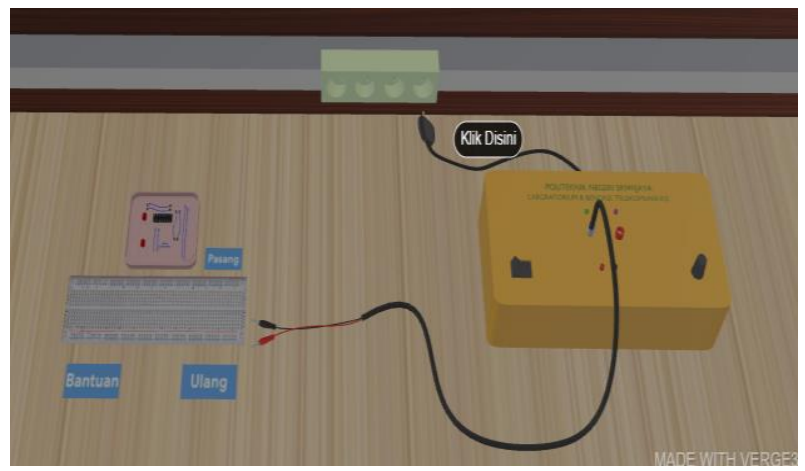

Figure 6 Protoboard component and design

For the first experiment, with the input switches $\mathrm{R}$ and $\mathrm{S}$ are 0 then the output Q and Q' from this experiment are 1 1 where the LED is on. To display the design results will be as shown in Figure. 7

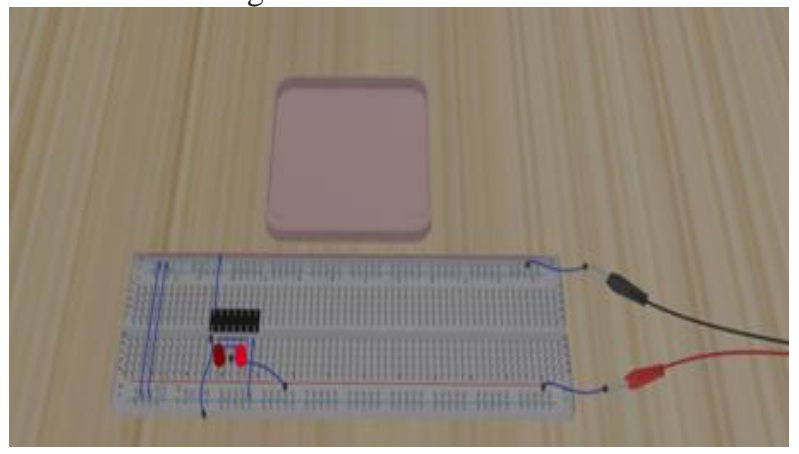

Figure 7 RS Flip flop circuit

For the second experiment, with the input switches R and $\mathrm{S}$ are 1, the outputs $\mathrm{Q}$ and $\mathrm{Q}$ ' from this experiment are Hold where the LED is in the same state as the previous experiment. To display the design results. For the third experiment, with the input switch $\mathrm{R}$ is 1 and $\mathrm{S}$ is 0 then the output Q and Q' from this experiment are 10 where the LED is on and off. To display the design results will be as shown in Figure8.

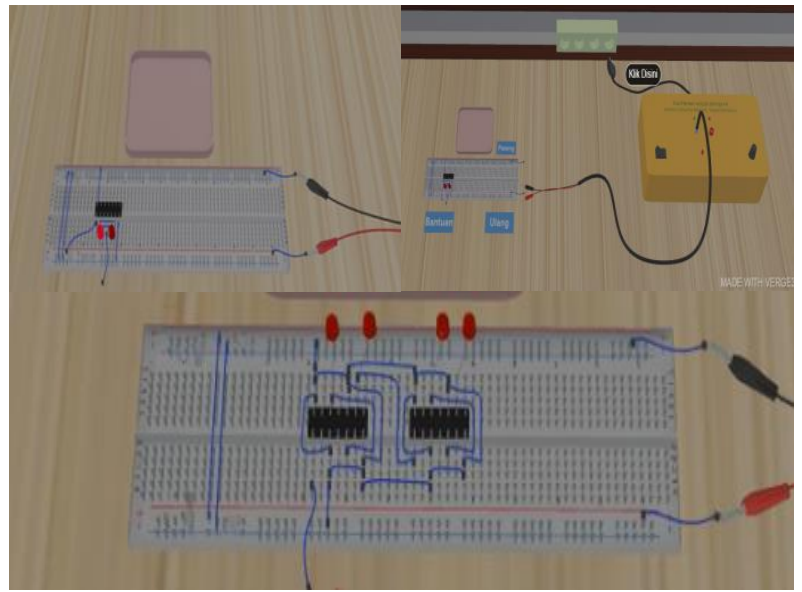

Figure 8 RS Flip Flop for R - S 1 and Q - Q’ 10

\section{CONCLUSION}

For the RS Flip Flop circuit experiment, the results of the animation design of the circuit, both classroom objects and practicum components, look perfect and clear. The output of this circuit is in accordance with the truth table. The response of the movement of the RS Flip Flop series animation runs quickly according to the animation settings.

For the Asynchronous Forward Counter series experiment, the results of the animation design of the series, both classroom objects and practicum components look perfect and clear. The output of this circuit is that the LED lights up from 0-15 in accordance with the truth table. The response from the animation movement of the Asynchronous Forward Counter series runs quickly according to the animation settings.

For the Asynchronous Reverse Counter series experiment, the results of the animation design of the series, both classroom objects and practicum components look perfect and clear. The output of this circuit is that the LED lights up from 15-0 in accordance with the truth table. The response from the animation movement of the Asynchronous Reverse Counter series runs quickly according to the animation settings.

\section{AUTHORS' CONTRIBUTIONS}

Contribution to the authors is making research data collection, with the testing how many disign and modelling in the blender. 


\section{ACKNOWLEDGMENTS}

In writing this paper, the researcher has conducted several sample trials with reference to references as reference material, to improve this paper.

\section{REFERENCES}

[1] Rizman, Nataša. (2015). Virtual Laboratory in Chemistry - Experimental Study of Understanding, Reproduction and Application of Acquired Knowledge of Subject's Chemical Content Organizacija, Volume 45.

[2] Yulianto, Dimas Agung. 2012. Pemodelan Virtual Reality Sebagai Media Promosi Digital Pada Perum Japunan Asri. Agustus 25, 2014. Teknik Informatika Fakultas Teknik Universitas Muhammadiyah Magelang.

[3] Abidin, Riswan. 2016. Pengertian Virtual Reality. https://teknojurnal.com.

[4] Sucipto, 2010. Penulisan Naskah Pembelajaran Multimedia Interaktif Berbantuan Komputer (Multimedia). Makalah. Yogyakarta: Balai Teknologi Komunikasi Pendidikan (BTKP)

[5] Suyanto, M. 2003. Multimedia Alat Untuk Meningkatkan Keunggulan Bersaing. Yogyakatra: Andi Yogyakarta.

[6] Phillips, Rob. The developer's handbook to interactive multimedia: a practical guide for educational applications. London: Kogan Page Ltd,1997.
[7] Sadiman, A.S. dkk., Media Pendidikan: Pengertian, Pengembangan dan Pemanfaatannya, Bandung: Remaja Rosdakarya, 2002.

[8] Amin, A. 2016. PEMBUATAN FILM ANIMASI CARA UMRAH SESUAI SOFTWARE BLENDER SKRIPSI Oleh : AINUL AMIN. Teknologi Pendidikan, 134.

[9] Ibiz Fernandes. Definisi Animasi "Macromedia Flash Animation \& Cartooning: A creative Guide", McGraw- Hill/Osborn, California, 2002

[10] Lacrama, D. 2007. Virtual Reality. Journal Anale Seria Informatica, 5(1) 137-144.

[11] M. Mihelj, D. Novak and S. Begus, Virtual Reality Technology and Applications, Vol. 68, London Springer, 2014.

[12] Ausburn, L J. 2009. A Cross-case Analysis of Gender Issues In Dekstop Virtual Reality Learning Environments. Journal of Industrial Teacher Education, 46(3) 51-89.

[13] Ausburn, L J. 2004. Dekstop Virtual Reality: A Powerful New Technology for Teaching and Research in Industrial Teacher Education. Journal of Industrial Teacher Education.41(4). http://scholar.lib.vt.edu/ejournals/JITE/v41n4/ ausburn .html.

[14] Hendratman, Hendi. 2015. The Magic of Blender 3D Modelling. Bandung: Informatika.

[15] Moeleong, L. 2013. Implementasi Cluster Computing Untuk Render Animasi. E-Jurnal Teknik Elektro dan Komputer Universitas Sam Ratulangi Manado. 